\title{
Effect of urbanization on heavy metal contamination: a study on major townships of Kannur District in Kerala, India
}

\author{
K. P. Shimod ${ }^{1 *}\left(\mathbb{D}\right.$, V. Vineethkumar $^{2}$, T. K. Prasad $^{1}$ and G. Jayapal ${ }^{1}$
}

\begin{abstract}
Background: In the last few decades, the air, water, and soil are contaminated due to different anthropogenic activities and severely affect the environmental quality. Pollution is the harmful effect and creates undesirable changes in the land use and land cover pattern. The growth of urbanization leads to the degradation of the ecosystem and ultimately affects the living and non-living organisms. In view of these, the present investigation is carried out to assess the heavy metal pollution in major towns due to the impact of urbanization in Kannur district and desirable conclusions were drawn.

Results: The results shows that higher level of heavy metal pollution is observed in major towns of Kannur district.

Conclusion: The heavy metal contamination in the major towns of Kannur district is mainly due the anthropogenic activities. The discharge of domestic effluents and industrial waste is the major source of heavy metal pollution. Indepth studies and proper waste management plans are needed to decrease the level of heavy metal contamination prevailing in the study area.
\end{abstract}

Keywords: Urbanization, Heavy metals, Pollution, Kerala

\section{Background}

The process of urbanization is a dynamic and multifaceted progression. The relationship between land use change and environmental quality has been affected by the rapid rate of urbanization, industrialization, rural land conversion, and unexpected growth of population which can cause the degradation in the environmental quality. The fast phase of urbanization causes series environmental issues and diverse kinds of pollution with evolution of time and technology and is sensitive in the accumulation of heavy metal contamination in both spatial and temporal aspects. The urban and economic growth plays a massive impact in polluting the environment by discharging the wastewater which inputs pollutants particularly of

\footnotetext{
*Correspondence: skp.orgin@gmail.com

1 Department of Geography, Kannur University, Payyanur Campus, Edat,

Kannur, Kerala 670327, India

Full list of author information is available at the end of the article
}

toxic heavy metals (Sin et al. 2001; Feng Peng et al. 2009). Thus, the accumulation of contaminants in the sediments of the rivers and other water sources acts as the sink for pollutants (Harbison 1986; Hoch 2001; Nasehi et al. 2013; Rigaud et al. 2013).

The potential risk caused by environmental pollution and the degradation of different environmental matrices have turned out to be an issue of global significance. Overexploitation of natural resources to satisfy the demands of an unsustainable pattern of development across the world has rendered it more vulnerable to deficiencies. The elevated levels of heavy metals in the environment cause series health risks to the living and non-living organisms (Santos et al. 2005). Many researches like Bryan and Langston (1992), Tam and Wong (1996), Tam and Wong (1997), Khan et al. (2000), McGrath et al. (2001), Alam et al. (2003), Veeresh et al. (2003), Banerjee (2003), Sharma et al. (2004), Krishna and Govil (2004), Rattan et al. (2005), Ray et al. (2006), Abbas 
et al. (2007), Krishna and Govil (2008), Pandey and Pandey (2009), Sekabira et al. (2010), Prakash et al. (2011), Parth et al. (2011), Krishna et al. (2013), Chandrasekaran et al. (2015), Zhao et al. (2016), Feng et al. (2017), Islam et al. (2017), Ribeiro et al. (2018), Fletcher et al. (2019), Chai et al. (2019), EL Turk et al. (2019), Sayooj et al. (2020), Wang et al. (2020) and Alfaifi et al. (2021) have carried out studies on heavy metal contamination in different environmental matrices.

The sources of heavy metals can be classified as natural and manmade sources (Parth et al. 2011). The natural source of heavy metals is the result of paedogenic process of weathering of parental rock materials in the environment. The natural distribution of heavy metals depends on the environmental conditions and the bed rock type (igneous rock, sedimentary rock and metamorphic rock) present in the area. Soil formation from the lithogenic sources also contributes considerable amount of heavy metal concentration. Several studies state that natural disasters like forest fire and volcanic eruption will also contribute to the high concentration of heavy metals (Seaward and Richardson 1989; Ross 1994; Nagajyoti et al. 2010). Anthropogenic sources are found to be the major sources of heavy metals when compared with the natural sources (He et al. 2013). The environment is always subjected to different anthropogenic activities like use of fertilizers in the agricultural fields, industrial activities, mining activities, combustion processes, smelters, transportation, disposal of commercial waste products, construction residues, and demolition wastes (Tokman et al. 2004).

In view of the above, major towns of Kannur district have been selected for the present study. The main objective of the study is to find out the impact of urbanization in the heavy metal pollution of Kannur district, Kerala, and the results were discussed in detail.

\section{Study area}

Kannur district was taken as the study area for the present investigation. It lies between latitudes $11^{\circ} 40^{\prime}$ to $12^{\circ}$ $48^{\prime} \mathrm{N}$ and longitude $74^{\circ} 52^{\prime}$ to $76^{\circ} 07^{\prime} \mathrm{E}$. The district is bound by the Western Ghats in the East (Coorg district of Karnataka state), Kozhikode and Wayanad district in the South, Lakshadweep Sea in the West, and Kasaragod, the northern most district of Kerala, in the North. The district has a total geographical area of $2966 \mathrm{sq} . \mathrm{km}$. which accounts about $7.64 \%$ of the total area of Kerala state.

The urban growth of an area can be assessed with the urban population content. As per 2011 census, the total population of the district is about 25,23,003 persons in which $15,68,875$ are treated as urban population. It ranks $8^{\text {th }}$ in total population, and 4th in the urban population among the districts of Kerala. Among the total population in the district, $65.04 \%$ lives in the urban area. This shows that urbanization process is rather fast in the district. Figure 1 shows the location map of the study area. The latitude and longitude of the sampling stations are given in Table 1.

\section{Methods}

In the present study, X-ray Fluorescence Spectrometer (XRF), (Model: SPECTRO XEPOS) is used to measure the concentration of heavy metals in soil samples collected from the major towns of Kannur district. Latitude and longitude of the location points were noted using Trimble Juno SA handheld GNSS Receiver, and the location maps and interpolation maps were created using Arc GIS software version 10.8 .

\section{Land use/land cover}

Land use/land cover (LULC) is defined as the physical composition, characteristics, and human activities in the surface of the earth (Cihlar 2000). The change in LULC is the rapid influence of human activities in the environment and followed by significant consequences. Anthropogenic activities play vital role in the land use and land cover changes which is commonly based on urban development. The accelerated growth of urban centres not only influences the socioeconomic changes, but also influences the biophysical environment ( $\mathrm{Li}$ and Yeh 2000). It will lead to the problems associated with the urban centres like that of solid waste management and the wastewater disposal. To address these developmental issues, it is essential to have scientific analysis to understand the urban growth pattern and processes.

Figure 2 shows the land use/land cover classification of Kannur, prepared from LANDSAT 8 OLI TIRS satellite image. The land use/land cover in the district is categorized under twelve classes, and the percentage area under different land use classes is: mixed crops with $35.14 \%$, followed by open scrub with $15.49 \%$, forest with $14.16 \%$, rubber plantation with $11.78 \%$, built-up with $7.53 \%$, cashew plantation with $3.66 \%$, paddy with $3.63 \%$, coconut plantation with $3.18 \%$ pepper plantation with $2.75 \%$, waterbodies with $1.78 \%$, marshy land with $0.62 \%$, and rocky outcrops with $0.28 \%$. The built-up is more prominent along the national high and coastal regions of the district, and more than half of the total population lives in these regions. The major towns in the district are also located in this region.

\section{Sample collection and elemental analysis}

Soil samples were collected from 20 different areas of major towns in Kannur district during the month of February 2019. Around $1 \mathrm{~m}^{2}$ area was marked for the sample 

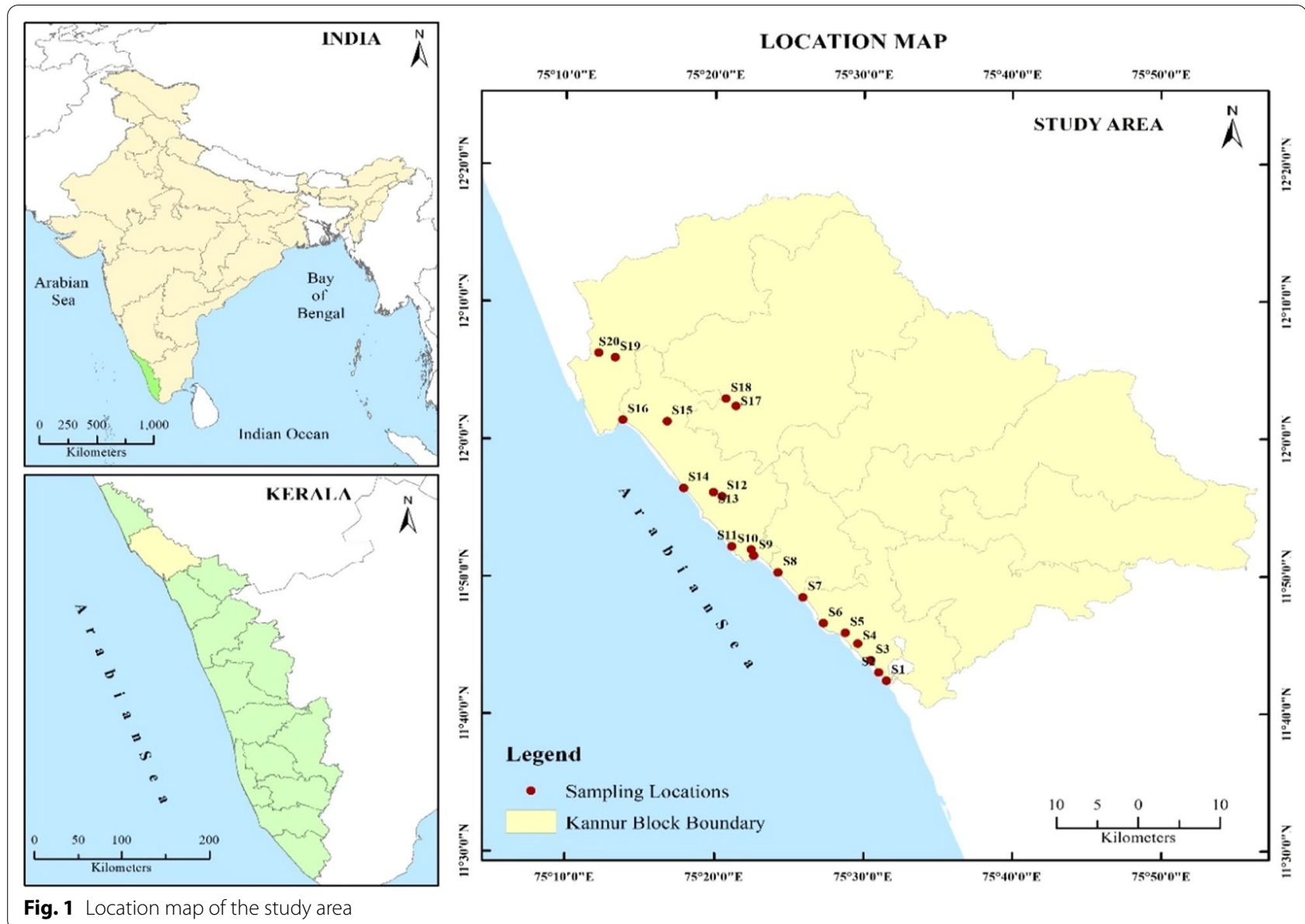

Fig. 1 Location map of the study area

collection with a depth of $30 \mathrm{~cm}$ and mixed thoroughly. The stones, pebbles, grass, and plant parts present on its surface were removed prior to the sample collection. Each sample collected was reduced to around $1 \mathrm{~kg}$ by quartering process. The thoroughly mixed samples were divided into four equal parts. By discarding the opposite ones, the remaining two parts were mixed again. This process was continued until $1 \mathrm{~kg}$ of soil sample was obtained and is taken as the representative sample. The samples were collected in polythene zip lock bags and brought to the laboratory for further analysis (Del Mastro et al. 2015 and Vineethkumar et al. 2020). The concentration of heavy metals such as lead $(\mathrm{Pb})$, arsenic (As), mercury $(\mathrm{Hg})$, cadmium $(\mathrm{Cd})$, zinc $(\mathrm{Zn})$, and iron $(\mathrm{Fe})$ in the collected samples was analysed using X-ray fluorescence spectrometer (XRF).

\section{Pollution indices}

Pollution indices are analysed for the understanding of environmental quality matrices and the hazard effects of the enrichment of heavy metals. To measure the assessment of degree of contamination in the environment due to the accumulation of heavy metals, five parameters are used which are enrichment factor $(\mathrm{EF})$, contamination factor $(\mathrm{CF})$, geo-accumulation index $\left(\mathrm{I}_{\text {geo }}\right)$, pollution load index (PLI), and degree of contamination $\left(C_{\mathrm{d}}\right)$. These parameters are the major indicators of level of pollution in the environment and will provide a comprehensive way to analyse the pollution status, distribution, and accumulation of heavy metals in the environment. Apparently, the quantitative ranking of heavy metal contamination in different sampling sites with respect to natural environment can be studied by these pollution indices (Ganugapenta et al. 2018).

\section{Enrichment factor (EF)}

Enrichment factor is the parameter used to estimate the degree of contamination in the soil due to heavy metals. It is widely used as normalization technique to assess the degree of metal contamination in soil. Assessment of enrichment factor is helpful to examine separate naturally existing metal from those resulting from anthropogenic interventions in the soil. It will also help for the estimation of intensity of deposition of pollutants from 
Table 1 The latitude and longitude of the sampling stations

\begin{tabular}{llll}
\hline Sample ID & Sampling stations & Latitude (decimal degree) & $\begin{array}{c}\text { Longitude } \\
\text { (decimal } \\
\text { degree) }\end{array}$ \\
\hline S1 & & & 75.525872 \\
S2 & New Mahe Beach & 11.707222 & 75.51733 \\
S3 & Punnol Beach & 11.71696 & 75.508522 \\
S4 & Thalassery Harbour & 11.73176 & 75.493728 \\
S5 & Thalassery Market & 11.751887 & 75.479859 \\
S6 & Co-operative Hospital, Thalassery & 11.765137 & 75.455309 \\
S7 & Dharmadam & 11.776638 & 75.432379 \\
S8 & Edakkad Beach & 11.808048 & 75.404228 \\
S9 & Aadi Kadalayi Beach & 11.838207 & 75.376928 \\
S10 & Mapila Bay Harbour & 11.858546 & 75.374405 \\
S11 & Kannur New Bus Stand & 11.865938 & 75.352376 \\
S12 & Payyambalam Beach & 11.869632 & 75.341374 \\
S13 & Valapattanam & 11.93025 & 75.331879 \\
S14 & Azhikkal Port Jetty & 11.935248 & 75.298398 \\
S15 & Azhikkal & 11.940422 & 75.27977 \\
S16 & Pazhayangadi & 12.021101 & 75.230058 \\
S17 & Chootad Beach & 12.022993 & 75.356653 \\
S18 & Thaliparamba & 12.039966 & 75.345656 \\
S19 & Kuppam Bridge & 12.048833 & 75.221173 \\
S20 & Perumba & 12.098552 & 75.202829 \\
\hline & Payyanur Rly Road & 12.104223 & \\
\end{tabular}

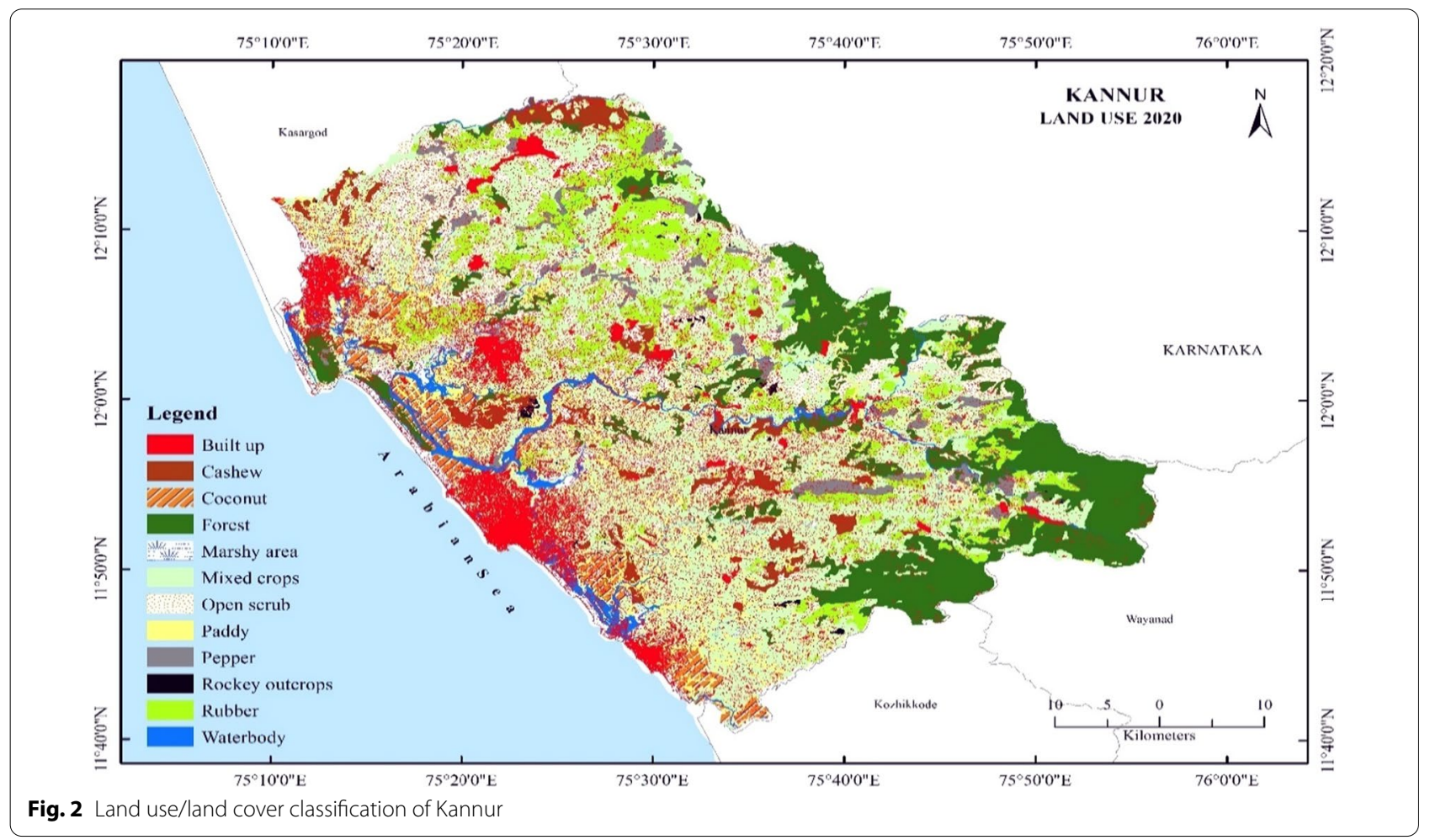


the anthropogenic activities. The enrichment factor is calculated based on a reference element concentration, which can be taken from local sites, where there is the deposition under similar conditions in the past without having any anthropogenic intrusion or from the composition of average in the regional or global level. In general, most of the studies use $\mathrm{Fe}$ or $\mathrm{Al}$ as the reference element. In the present study, Fe is taken as the reference element for the assessment of enrichment factor. The following equation is used to calculate the enrichment factor:

$$
\mathrm{EF}=\frac{\left(C_{x} / C_{\mathrm{Fe}}\right)_{\text {sediment }}}{\left(C_{x} / C_{\mathrm{Fe}}\right)_{\text {reference value }}}
$$

where $\left(C_{x} / C_{\mathrm{Fe}}\right)_{\text {sediment }}$ and $\left(C_{x} / C_{\mathrm{Fe}}\right)_{\text {reference value }}$ denote the concentration ratios of element ' $x$ ' to Fe in sediment sample and unpolluted reference baseline, respectively. The soil quality can be classified based on enrichment factor as shown in Table 2.

\section{Contamination factor (CF)}

The contamination factor is the ratio of metal concentration in the sediment sample to the reference value of that metal. This calculation is used to identify the pollution levels in the soil by the presence of heavy metals. This soil sample contamination can be measured using the contamination factor. This can be calculated using the following relation.

$$
\mathrm{CF}=\frac{\left(C_{x}\right)_{\text {sediment }}}{\left(C_{x}\right)_{\text {reference }}}
$$

where $\left(C_{x}\right)_{\text {sediment }}$ refers to the concentration of element ' $\mathrm{x}$ ' and $\left(C_{x}\right)$ reference is the concentration of reference element. The level of contamination can be classified on the basis of CF as shown in Table 3.

\section{Geo-accumulation index $\left(I_{\text {geo }}\right)$}

The geo-accumulation index was proposed by Muller, a German scientist in the year 1979, to determine the concentration of accumulation of metal in the sediments by comparing the present with pre-industrial levels. This can be used to determine the contamination

Table 2 Classification of enrichment factor

\begin{tabular}{ll}
\hline Enrichment factor & Soil quality \\
\hline $\mathrm{EF}<2$ & Deficiency to minimal enrichment \\
$2<\mathrm{EF}<5$ & Moderate enrichment \\
$5<\mathrm{EF}<20$ & Significant enrichment \\
$20<\mathrm{EF}<40$ & Very high enrichment \\
$\mathrm{EF}>40$ & Extremely high enrichment
\end{tabular}

Veerasingam et al. (2012) and Petrelli et al. (2016)
Table 3 Classification of contamination factor

\begin{tabular}{ll}
\hline Contamination factor & Contamination level \\
\hline $\mathrm{CF}<1$ & Low contamination \\
$1 \leq \mathrm{CF}<3$ & Moderate contamination \\
$3 \leq \mathrm{CF}<6$ & Considerable contamination \\
$\mathrm{CF}>6$ & Very high contamination \\
\hline
\end{tabular}

Vineethkumar et al. (2020) and Sheela et al. (2012)

of aquatic sediments by organic and inorganic substances. The geo-accumulation index can be calculated by the following relation.

$$
I_{\text {geo }}=\log _{2}\left(\frac{C x}{1.5 \times B x}\right)
$$

where $C x$ is the concentration of metal ' $x$ ' in the sediment and $B x$ is the geo-chemical background value of metal ' $x$ '. The factor 1.5 is used in the equation to compensate the variations in background data due to lithogenic effects. The pollution intensity can be classified on the basis of $I_{\text {geo }}$ as shown in Table 4.

\section{Pollution load index (PLI)}

Pollution load index (PLI) is used to determine the integrated pollution level of combined toxicant pollutants present in the soil samples and provide the extend of pollution by heavy metals in the soil. It is also used to assess the overall soil toxicity. The following equation is used to calculate pollution load index.

$$
\mathrm{PLI}=\left[\mathrm{CF}_{1} \times \mathrm{CF}_{2} \times \mathrm{CF}_{3} \times \cdots \times \mathrm{CF}_{n}\right]^{1 / n}
$$

where $\mathrm{CF}_{n}$ is the value of contamination factor for metal ' $n$ ' and ' $n$ ' is the number of metals present in the analysis. The classification of pollution level on the basis of PLI is shown in Table 5.

Table 4 Classification of geo-accumulation index

\begin{tabular}{lll}
\hline $\begin{array}{l}\text { Geo-accumulation } \\
\text { index }\end{array}$ & $\boldsymbol{I}_{\text {geo }}$ class & Pollution intensity \\
\hline$>5$ & 6 & Very strongly polluted \\
$>4-5$ & 5 & Strong to very strongly polluted \\
$>3-4$ & 4 & Strongly polluted \\
$>2-3$ & 3 & Moderately to strongly polluted \\
$>1-2$ & 2 & Moderately polluted \\
$>0-1$ & 1 & Unpolluted to moderate polluted \\
$<0$ & 0 & Practically unpolluted \\
\hline
\end{tabular}

Asa et al. (2013) and Vineethkumar et al. (2020) 
Table 5 Classification of pollution load index

\begin{tabular}{ll}
\hline Pollution load index & Pollution level \\
\hline$\leq 1$ & No metal pollution \\
$>1$ & Metal pollution exist \\
\hline (Vineethkumar et al. 2020; Tholkappian et al. 2018) &
\end{tabular}

Table 6 Classification of degree of contamination

\begin{tabular}{ll}
\hline $\boldsymbol{C}_{\mathbf{d}}$ levels & Degree of contamination \\
\hline$C_{d}<8$ & Low degree of contamination \\
$8 \leq C_{d}<16$ & Moderate degree of contamination \\
$16 \leq C_{d}<32$ & Considerable degree of contamination \\
$C_{d} \geq 32$ & Very high degree of contamination \\
& indicating serious anthropogenic \\
& pollution \\
\hline
\end{tabular}

Bramha et al. (2014) and Sivakumar et al. (2016)

\section{Degree of contamination $\left(C_{d}\right)$}

Degree of contamination $\left(C_{\mathrm{d}}\right)$ is the sum of all the contamination factors (CF) for a given set of samples. It is calculated using the following relation.

$$
C_{\mathrm{d}}=\sum \mathrm{CF}
$$

where $\mathrm{CF}$ is the contamination factor. The classification of contamination status on the basis of modified degree of contamination is shown in Table 6.

\section{Results}

The concentration of heavy metals in the soil samples collected from different locations of Kannur district is given in Table 7. The pollution indices such as enrichment factor, contamination factor, geo-accumulation index, pollution load index, and degree of contamination are summarized in Tables 8, 9, 10 and 11, respectively. The spatial distribution of heavy metals in the soil samples collected from different parts of Kannur district is shown in Fig. 3. The spatial distribution of enrichment factor, contamination factor, geo-accumulation index, pollution load index and degree of contamination is given in Figs. 4, 5, 6 and 7, respectively.

\section{Discussion}

The concentration of $\mathrm{Pb}$ in soil samples collected from different environs of Kannur district ranges from 7.3 ppm (Chootad Beach) to 725.1 ppm (Kannur New Bus Stand)

Table 7 Concentration of heavy metals in soil samples of Kannur district

\begin{tabular}{|c|c|c|c|c|c|c|c|}
\hline Sample ID & Sampling location & $\mathrm{Pb}(\mathrm{ppm})$ & As (ppm) & $\mathrm{Hg}(p p m)$ & Cd (ppm) & Zn (ppm) & $\mathrm{Fe}(\mathrm{ppm})$ \\
\hline S1 & New Mahe Beach & 17.1 & 3.4 & 0.9 & 0.4 & 12.4 & $23,876.6$ \\
\hline $\mathrm{S} 2$ & Punnol Beach & 11.2 & 0.8 & 0.7 & 0.4 & 2.1 & $18,954.8$ \\
\hline S3 & Thalassery Harbour & 327.3 & 11.2 & 8.6 & 0.7 & 112.3 & $65,798.3$ \\
\hline S4 & Thalassery Market & 647.3 & 17.8 & 11.7 & 6.4 & 189.3 & $86,574.5$ \\
\hline S5 & Co-operative Hospital, Thalassery & 478.4 & 19.3 & 9.1 & 2.3 & 134.2 & $78,564.2$ \\
\hline S6 & Dharmadam Beach & 45.3 & 1.8 & 1.6 & 0.8 & 14.3 & $13,897.3$ \\
\hline S7 & Edakkad Beach & 8.4 & 0.7 & 0.7 & 0.5 & 1.5 & $16,457.1$ \\
\hline S8 & Aadi Kadalayi Beach & 19.8 & 0.8 & 0.6 & 0.6 & 6.5 & $13,478.4$ \\
\hline S9 & Mapila Bay Harbour & 234.7 & 13.2 & 1.1 & 1.3 & 75.6 & $58,724.2$ \\
\hline $\mathrm{S} 10$ & Kannur New Bus Stand & 725.1 & 21.3 & 12.4 & 7.3 & 210.4 & $97,874.3$ \\
\hline $\mathrm{S} 11$ & Payyambalam Beach & 16.3 & 0.9 & 0.7 & 0.4 & 7.5 & $14,657.1$ \\
\hline $\mathrm{S} 12$ & Valapattanam & 456.5 & 4.5 & 6.4 & 1.4 & 124.3 & $42,664.2$ \\
\hline $\mathrm{S} 13$ & Azhikkal Port Jetty & 513.8 & 16.8 & 8.7 & 4.6 & 98.4 & $84,235.3$ \\
\hline S14 & Azhikkal & 478.3 & 14.3 & 6.5 & 4.3 & 112.4 & $65,427.6$ \\
\hline $\mathrm{S} 15$ & Pazhayangadi & 98.3 & 1.2 & 1.1 & 0.8 & 12.3 & $24,983.3$ \\
\hline S16 & Chootad Beach & 7.3 & 0.8 & 0.8 & 0.3 & 4.3 & $11,564.2$ \\
\hline $\mathrm{S} 17$ & Thaliparamba & 398.9 & 14.8 & 7.3 & 1.9 & 126.7 & $65,124.5$ \\
\hline $\mathrm{S} 18$ & Kuppam Bridge & 75.4 & 2.7 & 4.1 & 0.9 & 90.2 & $58,463.4$ \\
\hline S19 & Perumba & 24.8 & 12.4 & 2.3 & 0.8 & 64.2 & $47,569.3$ \\
\hline $\mathrm{S} 20$ & Payyanur Rly Road & 156.3 & 8.7 & 4.3 & 1.4 & 63.5 & $34,785.6$ \\
\hline Minimum & & 7.3 & 0.7 & 0.6 & 0.3 & 1.5 & $11,564.2$ \\
\hline Maximum & & 725.1 & 21.3 & 12.4 & 7.3 & 210.4 & $97,874.3$ \\
\hline Mean & & 237.025 & 8.37 & 4.48 & 1.875 & 73.12 & $46,183.71$ \\
\hline Standard Deviation & & 242.373 & 7.341 & 4.020 & 2.084 & 64.990 & $28,323.77$ \\
\hline
\end{tabular}


Table 8 Enrichment factor

\begin{tabular}{|c|c|c|c|c|c|c|}
\hline Sample ID & Sampling location & $\mathrm{Pb}(\mathrm{ppm})$ & As (ppm) & $\mathrm{Hg}(\mathrm{ppm})$ & $\mathrm{Cd}(\mathrm{ppm})$ & $\mathrm{Zn}$ (ppm) \\
\hline S1 & New Mahe Beach & 1.69 & 0.517 & 4.448 & 2.636 & 0.258 \\
\hline $\mathrm{S} 2$ & Punnol Beach & 1.394 & 0.153 & 4.358 & 3.32 & 0.055 \\
\hline S3 & Thalassery Harbour & 11.739 & 0.618 & 15.423 & 1.674 & 0.848 \\
\hline S4 & Thalassery Market & 17.645 & 0.746 & 15.947 & 11.631 & 1.086 \\
\hline S5 & Co-operative Hospital, Thalassery & 14.371 & 0.892 & 13.668 & 4.606 & 0.849 \\
\hline S6 & Dharmadam Beach & 7.693 & 0.47 & 13.585 & 9.057 & 0.511 \\
\hline S7 & Edakkad Beach & 1.205 & 0.154 & 4.302 & 4.78 & 0.045 \\
\hline S8 & Aadi Kadalayi Beach & 3.467 & 0.189 & 5.253 & 7.004 & 0.24 \\
\hline S9 & Mapila Bay Harbour & 9.432 & 0.816 & 2.21 & 3.483 & 0.64 \\
\hline $\mathrm{S} 10$ & Kannur New Bus Stand & 17.484 & 0.79 & 14.95 & 11.735 & 1.068 \\
\hline $\mathrm{S} 11$ & Payyambalam Beach & 2.625 & 0.223 & 5.635 & 4.294 & 0.254 \\
\hline $\mathrm{S} 12$ & Valapattanam & 25.252 & 0.383 & 17.701 & 5.163 & 1.448 \\
\hline $\mathrm{S} 13$ & Azhikkal Port Jetty & 14.395 & 0.724 & 12.187 & 8.592 & 0.58 \\
\hline $\mathrm{S} 14$ & Azhikkal & 17.252 & 0.794 & 11.723 & 10.34 & 0.854 \\
\hline $\mathrm{S} 15$ & Pazhayangadi & 9.286 & 0.174 & 5.195 & 5.038 & 0.245 \\
\hline S16 & Chootad Beach & 1.49 & 0.251 & 8.163 & 4.082 & 0.185 \\
\hline $\mathrm{S} 17$ & Thaliparamba & 14.455 & 0.825 & 13.227 & 4.59 & 0.967 \\
\hline $\mathrm{S} 18$ & Kuppam Bridge & 3.044 & 0.168 & 8.275 & 2.422 & 0.767 \\
\hline $\mathrm{S} 19$ & Perumba & 1.23 & 0.946 & 5.705 & 2.646 & 0.671 \\
\hline $\mathrm{S} 20$ & Payyanur Rly Road & 10.604 & 0.908 & 14.586 & 6.332 & 0.907 \\
\hline Minimum & & 1.205 & 0.153 & 2.21 & 1.674 & 0.045 \\
\hline Maximum & & 17.645 & 0.946 & 17.701 & 11.735 & 1.448 \\
\hline Mean & & 9.288 & 0.537 & 9.827 & 5.671 & 0.624 \\
\hline Standard deviation & & 7.155 & 0.299 & 4.914 & 3.076 & 0.390 \\
\hline
\end{tabular}

Table 9 Contamination factor

\begin{tabular}{|c|c|c|c|c|c|c|c|}
\hline Sample ID & Sampling location & $\mathrm{Pb}(\mathrm{ppm})$ & As (ppm) & $\mathrm{Hg}(\mathrm{ppm})$ & $\mathrm{Cd}(\mathrm{ppm})$ & Zn (ppm) & $\mathrm{Fe}(\mathrm{ppm})$ \\
\hline S1 & New Mahe Beach & 0.855 & 0.262 & 2.25 & 1.333 & 0.131 & 0.506 \\
\hline S2 & Punnol Beach & 0.56 & 0.062 & 1.75 & 1.333 & 0.022 & 0.402 \\
\hline S3 & Thalassery Harbour & 16.365 & 0.862 & 21.5 & 2.333 & 1.182 & 1.394 \\
\hline S4 & Thalassery Market & 32.365 & 1.369 & 29.25 & 21.333 & 1.993 & 1.834 \\
\hline S5 & Co-operative Hospital, Thalassery & 23.92 & 1.485 & 22.75 & 7.667 & 1.413 & 1.664 \\
\hline S6 & Dharmadam Beach & 2.265 & 0.138 & 4.0 & 2.667 & 0.151 & 0.294 \\
\hline S7 & Edakkad Beach & 0.42 & 0.054 & 1.5 & 1.667 & 0.016 & 0.349 \\
\hline S8 & Aadi Kadalayi Beach & 0.99 & 0.054 & 1.5 & 2.0 & 0.068 & 0.286 \\
\hline S9 & Mapila Bay Harbour & 11.735 & 1.015 & 2.75 & 4.333 & 0.796 & 1.244 \\
\hline $\mathrm{S} 10$ & Kannur New Bus Stand & 36.255 & 1.638 & 31.0 & 24.333 & 2.215 & 2.074 \\
\hline $\mathrm{S} 11$ & Payyambalam Beach & 0.815 & 0.069 & 1.75 & 1.333 & 0.079 & 0.311 \\
\hline $\mathrm{S} 12$ & Valapattanam & 22.825 & 0.346 & 16.0 & 4.667 & 1.308 & 0.904 \\
\hline S13 & Azhikkal Port Jetty & 25.69 & 1.292 & 21.75 & 15.333 & 1.036 & 1.785 \\
\hline $\mathrm{S} 14$ & Azhikkal & 23.915 & 1.1 & 16.25 & 14.333 & 1.183 & 1.386 \\
\hline $\mathrm{S} 15$ & Pazhayangadi & 4.915 & 0.092 & 2.75 & 2.667 & 0.129 & 0.529 \\
\hline S16 & Chootad Beach & 0.365 & 0.062 & 2.0 & 1.0 & 0.045 & 0.245 \\
\hline $\mathrm{S} 17$ & Thaliparamba & 19.945 & 1.138 & 18.25 & 6.333 & 1.334 & 1.38 \\
\hline $\mathrm{S} 18$ & Kuppam Bridge & 3.77 & 0.208 & 10.25 & 3.0 & 0.949 & 1.239 \\
\hline S19 & Perumba & 1.24 & 0.954 & 5.75 & 2.667 & 0.676 & 1.008 \\
\hline $\mathrm{S} 20$ & Payyanur Rly Road & 7.815 & 0.669 & 10.75 & 4.667 & 0.668 & 0.737 \\
\hline Minimum & & 0.365 & 0.054 & 1.5 & 1.0 & 0.016 & 0.245 \\
\hline Maximum & & 36.255 & 1.638 & 29.25 & 24.333 & 2.215 & 1.834 \\
\hline Mean & & 11.851 & 0.643 & 11.188 & 6.250 & 0.770 & 0.979 \\
\hline Standard deviation & & 12.119 & 0.565 & 10.063 & 6.946 & 0.684 & 0.600 \\
\hline
\end{tabular}


Table 10 Geo-accumulation index

\begin{tabular}{|c|c|c|c|c|c|c|c|}
\hline Sample ID & Sampling location & $\mathrm{Pb}(\mathrm{ppm})$ & As (ppm) & $\mathrm{Hg}(\mathrm{ppm})$ & $\mathrm{Cd}(\mathrm{ppm})$ & $\mathrm{Zn}(\mathrm{ppm})$ & $\mathrm{Fe}(\mathrm{ppm})$ \\
\hline S1 & New Mahe Beach & -4.15 & -2.52 & 0.585 & -0.17 & -3.523 & -1.568 \\
\hline S2 & Punnol Beach & -4.427 & -4.607 & 0.222 & -0.17 & -6.084 & -1.901 \\
\hline S3 & Thalassery Harbour & -1.354 & -0.8 & 3.841 & 0.637 & -0.344 & -0.106 \\
\hline S4 & Thalassery Market & -0.766 & -0.132 & 4.285 & 3.83 & 0.41 & 0.29 \\
\hline S5 & Co-operative Hospital, Thalassery & -1.062 & -0.015 & 3.923 & 2.354 & -0.087 & 0.15 \\
\hline S6 & Dharmadam Beach & -1.963 & -3.437 & 1.415 & 0.83 & -3.317 & -2.349 \\
\hline S7 & Edakkad Beach & -4.638 & -4.8 & 0 & 0.152 & -6.57 & -2.105 \\
\hline S8 & Aadi Kadalayi Beach & -3.113 & -4.8 & 0 & 0.415 & -4.454 & -2.393 \\
\hline s9 & Mapila Bay Harbour & -1.669 & -0.563 & 0.874 & 1.531 & -0.915 & -0.27 \\
\hline $\mathrm{S} 10$ & Kannur New Bus Stand & -0.779 & 0.127 & 4.369 & 4.02 & 0.562 & 0.467 \\
\hline S11 & Payyambalam Beach & -3.515 & -4.437 & 0.222 & -0.17 & -4.248 & -2.272 \\
\hline $\mathrm{S} 12$ & Valapattanam & -0.249 & -2.115 & 3.415 & 1.637 & -0.197 & -0.731 \\
\hline $\mathrm{S} 13$ & Azhikkal Port Jetty & -1.059 & -0.215 & 3.858 & 3.354 & -0.534 & 0.251 \\
\hline S14 & Azhikkal & -0.798 & -0.447 & 3.437 & 3.256 & -0.342 & -0.114 \\
\hline S15 & Pazhayangadi & -1.692 & -4.022 & 0.874 & 0.83 & -3.534 & -1.503 \\
\hline$S 16$ & Chootad Beach & -4.332 & -4.607 & 0.415 & -0.585 & -5.05 & -2.614 \\
\hline S17 & Thaliparamba & -1.053 & -0.398 & 3.605 & 2.078 & -0.17 & -0.121 \\
\hline $\mathrm{S} 18$ & Kuppam Bridge & -3.301 & -2.852 & 2.773 & 1.0 & -0.66 & -0.276 \\
\hline S19 & Perumba & -4.608 & -0.653 & 1.939 & 0.83 & -1.15 & -0.574 \\
\hline S20 & Payyanur Rly Road & -1.5 & -1.164 & 2.841 & 1.637 & -1.166 & -1.025 \\
\hline Minimum & & -4.638 & -4.8 & 0 & -0.585 & -6.57 & -2.614 \\
\hline Maximum & & -0.249 & 0.127 & 4.369 & 4.02 & 0.562 & 0.467 \\
\hline Mean & & -2.301 & -2.123 & 2.145 & 1.365 & -2.069 & -0.938 \\
\hline Standard deviation & & 1.525 & 1.895 & 1.632 & 1.397 & 2.282 & 1.048 \\
\hline
\end{tabular}

with a mean value of $237.03 \mathrm{ppm}$. The mean value of the concentration of $\mathrm{Pb}$ exceeds the crustal average value of $20 \mathrm{ppm}$ (Turkian and Wedpohl 1961; Vineethkumar et al. 2020). The enrichment factor of $\mathrm{Pb}$ varies in the range 1.21 (Edakkad Beach) to 17.65 (Thalassery Market) with a mean value of 9.29. Significant enrichment of $\mathrm{Pb}$ is observed in most of the sampling stations. The contamination factor of $\mathrm{Pb}$ varies from 0.37 (Chootad Beach) to 36.26 (Kannur New Bus Stand) with a mean value of 11.85. The results indicate that a very high contamination of $\mathrm{Pb}$ is observed in most of the sampling points. Geoaccumulation index of $\mathrm{Pb}$ ranges from -4.638 (Edakkad Beach) to -0.249 (Valapattanam) with a mean value of -2.301 . The study area is practically unpolluted due to the presence of $\mathrm{Pb}$.

The concentration of As in the collected soil samples varies in the range $0.7 \mathrm{ppm}$ (Edakkad Beach) to $21.3 \mathrm{ppm}$ (Kannur New Bus Stand) with a mean value of $8.37 \mathrm{ppm}$. The mean value concentration of As is lower than the crustal average value of $13 \mathrm{ppm}$ (Turkian and Wedpohl 1961; Vineethkumar et al. 2020). The enrichment factor of As varies from 0.153 (Punnol Beach) to 0.946 (Perumba) with a mean value of 0.537. Deficiency to minimal enrichment of As is observed in all the sampling stations. The contamination factor of As ranges from 0.054 (Edakkad Beach) to 1.638 (Kannur New Bus Stand) with
Table 11 Pollution load index and degree of contamination

\begin{tabular}{lllc}
\hline Sample ID & Sampling location & PLI & \multicolumn{1}{c}{$\boldsymbol{C}_{\mathrm{d}}$} \\
\hline S1 & New Mahe Beach & 0.595 & 5.336 \\
S2 & Punnol Beach & 0.299 & 4.129 \\
S3 & Thalassery Harbour & 3.244 & 43.636 \\
S4 & Thalassery Market & 6.825 & 88.144 \\
S5 & Co-operative Hospital, Thalassery & 4.942 & 58.898 \\
S6 & Dharmadam Beach & 0.728 & 9.515 \\
S7 & Edakkad Beach & 0.26 & 4.005 \\
S8 & Aadi Kadalayi Beach & 0.382 & 4.898 \\
S9 & Mapila Bay Harbour & 2.28 & 21.874 \\
S10 & Kannur New Bus Stand & 7.684 & 97.515 \\
S11 & Payyambalam Beach & 0.384 & 4.357 \\
S12 & Valapattanam & 2.978 & 46.05 \\
S13 & Azhikkal Port Jetty & 5.23 & 66.886 \\
S14 & Azhikkal & 4.645 & 58.168 \\
S15 & Pazhayangadi & 0.782 & 11.083 \\
S16 & Chootad Beach & 0.282 & 3.717 \\
S17 & Thaliparamba & 4.111 & 48.38 \\
S18 & Kuppam Bridge & 1.746 & 19.416 \\
S19 & Perumba & 1.52 & 12.294 \\
S20 & Payyanur Rly Road & 2.249 & 25.306 \\
Minimum & & 0.26 & 3.717 \\
Maximum & & 7.684 & 97.515 \\
Mean & & 2.558 & 31.680 \\
Standard deviation & & 2.317 & 29.803 \\
\hline & & &
\end{tabular}



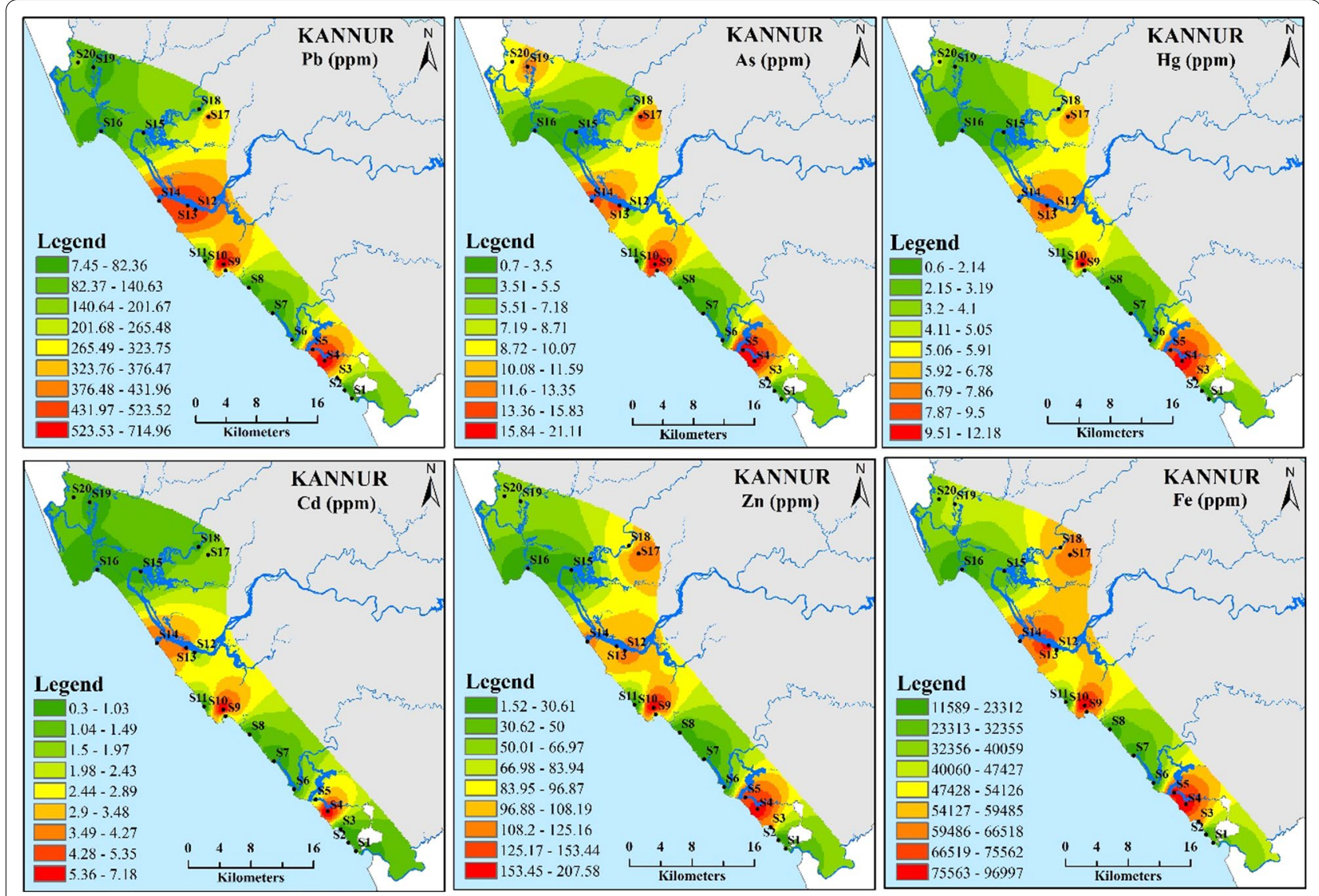

Fig. 3 Spatial distribution of heavy metals in soil samples of Kannur district

a mean value 0.643 . From the results, it is clear that the study area is less contaminated by the presence of As. Geo-accumulation index of As ranges from - 4.8 (Edakkad Beach and Aadi Kadalayi Beach) to 0.127 (Kannur New Bus Stand) with a mean value of -2.123 . The major towns of Kannur district are practically unpolluted due to the presence of As except Kannur New Bus Stand region. This area comes under the classification of unpolluted to moderately polluted by the presence of As.

The concentration of $\mathrm{Hg}$ in the soil samples varies from $0.6 \mathrm{ppm}$ (Aadi Kadalayi Beach) to 12.4 ppm (Kannur New Bus Stand) with a mean value of $4.48 \mathrm{ppm}$. The mean value of the concentration of $\mathrm{Hg}$ is higher than the suggested crustal average value of $0.4 \mathrm{ppm}$ (Turkian and Wedpohl 1961; Vineethkumar et al. 2020). The enrichment factor of $\mathrm{Hg}$ ranges from 2.21 (Mapila Bay Harbour) to 17.70 (Valapattanam) with a mean value of 9.83. Significant enrichment of $\mathrm{Hg}$ is observed in most of the sampling stations. The contamination factor of $\mathrm{Hg}$ varies in the range 1.5 (Edakkad Beach and Aadi Kadalayi Beach) to 29.25 (Thalassery Market) with a mean value of 11.19. Very high contamination of $\mathrm{Hg}$ is observed in most of the sampling stations. Geo-accumulation index of $\mathrm{Hg}$ varies from zero (Edakkad Beach and Aadi Kadalayi Beach) to 4.369 (Kannur New Bus Stand) with a mean value of 2.145. Most of the sampling locations are strongly polluted due the presence of $\mathrm{Hg}$.

The concentration of $\mathrm{Cd}$ in the collected soil samples ranges from $0.3 \mathrm{ppm}$ (Chootad Beach) to 6.4 ppm (Kannur New Bus Stand) with a mean value of $1.88 \mathrm{ppm}$. The mean value of the concentration of $\mathrm{Cd}$ is higher than the crustal average value of $0.3 \mathrm{ppm}$ (Turkian and Wedpohl 1961; Vineethkumar et al. 2020). The enrichment factor of Cd varies in the range 1.67 (Thalassery Harbour) to 11.74 (Kannur New Bus Stand) with a mean value of 5.67. Moderate enrichment of $\mathrm{Cd}$ is observed in most of the sampling stations. The contamination factor of $\mathrm{Cd}$ varies from 1.0 (Chootad Beach) to 24.33 (Kannur New Bus Stand) with a mean value of 6.25. Moderate contamination of $\mathrm{Cd}$ is observed in most of the sampling stations. Geo-accumulation index of $\mathrm{Cd}$ ranges from -0.585 (Chootad Beach) to 4.02 (Kannur New Bus Stand) with a mean value of 1.365. Major portion of the study area falls 


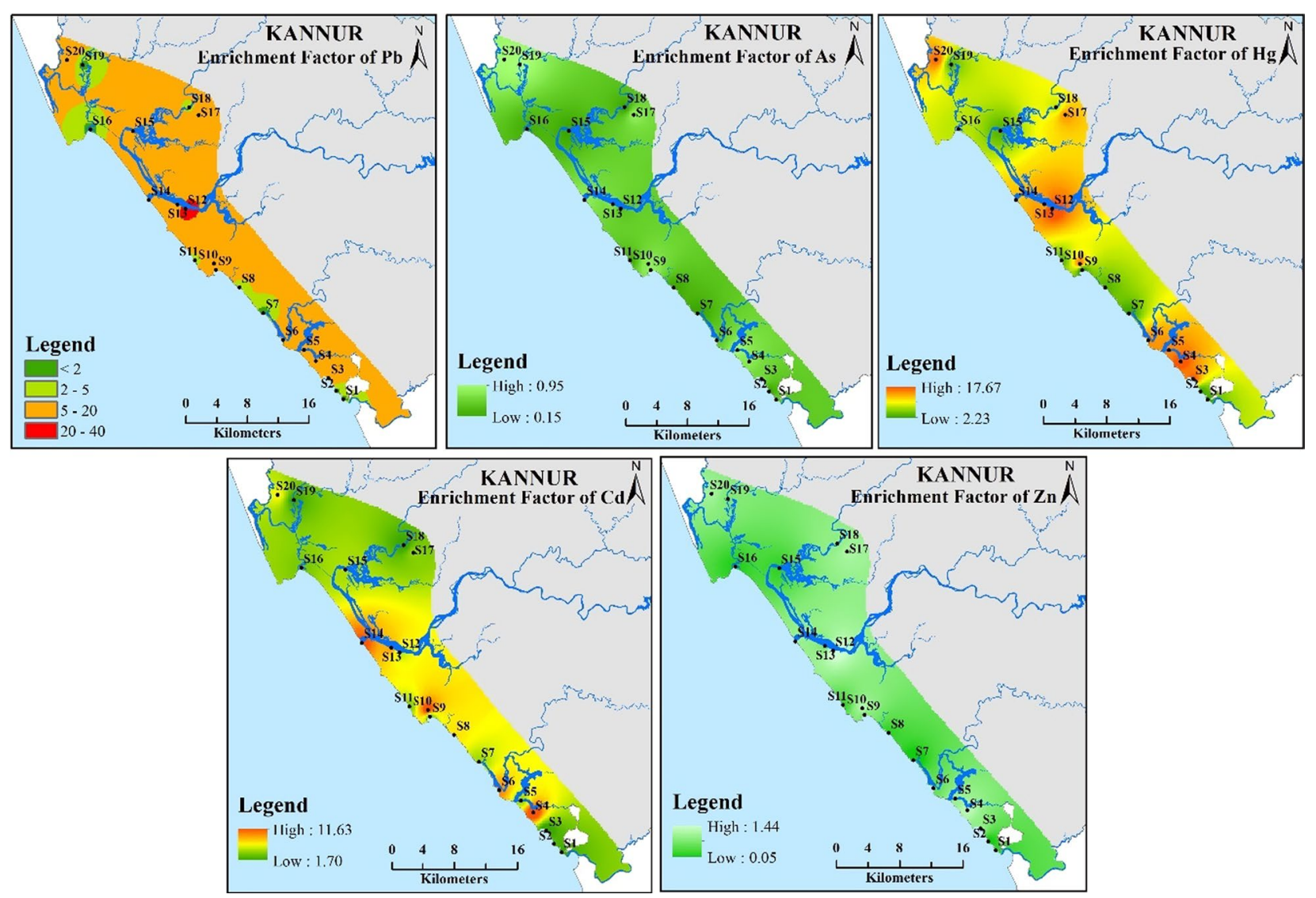

Fig. 4 Spatial distribution of enrichment factor of heavy metals

under practically unpolluted category with the presence of Cd.

The concentration of $\mathrm{Zn}$ in the collected soil samples varies in the range $1.5 \mathrm{ppm}$ (Edakkad Beach) to 210.4 ppm (Kannur New Bus Stand) with a mean value of $73.12 \mathrm{ppm}$. The mean value of the concentration of $\mathrm{Zn}$ is lower than the suggested crustal average value of $95 \mathrm{ppm}$ (Turkian and Wedpohl 1961; Vineethkumar et al. 2020). The enrichment factor of $\mathrm{Zn}$ ranges from 0.05 (Edakkad Beach) to 1.45 (Valapattanam) with a mean value 0.62 . Deficiency to minimal enrichment of $\mathrm{Zn}$ is observed in most of the sampling stations. The contamination factor of $\mathrm{Zn}$ varies from 0.016 (Edakkad Beach) to 2.215 (Kannur New Bus Stand) with a mean value of 0.77. Low contamination of $\mathrm{Zn}$ is noticed in most of the sampling points in the study area. Geo-accumulation index of $\mathrm{Zn}$ ranges from -6.57 (Edakkad Beach) to 0.562 (Kannur New Bus Stand) with a mean value of -2.069 . All the area under present study is practically unpolluted except Kannur New Bus Stand and Thalassery Market region.

The concentration of $\mathrm{Fe}$ in the collected soil samples varies from 11,564.2 ppm (Chootad Beach) to
97,874.3 ppm (Kannur New Bus Stand) with a mean value of $46,183.71 \mathrm{ppm}$. The mean value of the concentration of $\mathrm{Fe}$ is lower than the crustal average value of 47,200 ppm (Turkian and Wedpohl 1961; Vineethkumar et al. 2020). Contamination factor of $\mathrm{Fe}$ ranges from 0.245 (Chootad Beach) to 1.834 (Thalassery Market), with a mean value of 0.979 . The contamination of $\mathrm{Fe}$ is low in most of the sampling locations. Geo-accumulation index of Fe varies from - 2.614 (Chootad Beach) to 0.467 (Kannur New Bus Stand) with a mean value of -0.938 . Most of the study area is practically unpolluted due the presence of Fe.

The pollution load index and degree of contamination are shown in Table 11. The pollution load index varies from 0.26 (Edakkad Beach) to 7.684 (Kannur New Bus Stand) with a mean value of 2.558 . The results indicate that severe heavy metal pollution exists in the sampling locations such as Thalassery Harbour, Thalassery Market, Co-operative Hospital Thalassery, Mapila Bay Harbour, Kannur New Bus Stand, Valapattanam, Azhikkal Port Jetty, Azhikkal, Thaliparamba, Kuppam Bridge, Perumba, and Payyanur Railway Station Road. The degree of 

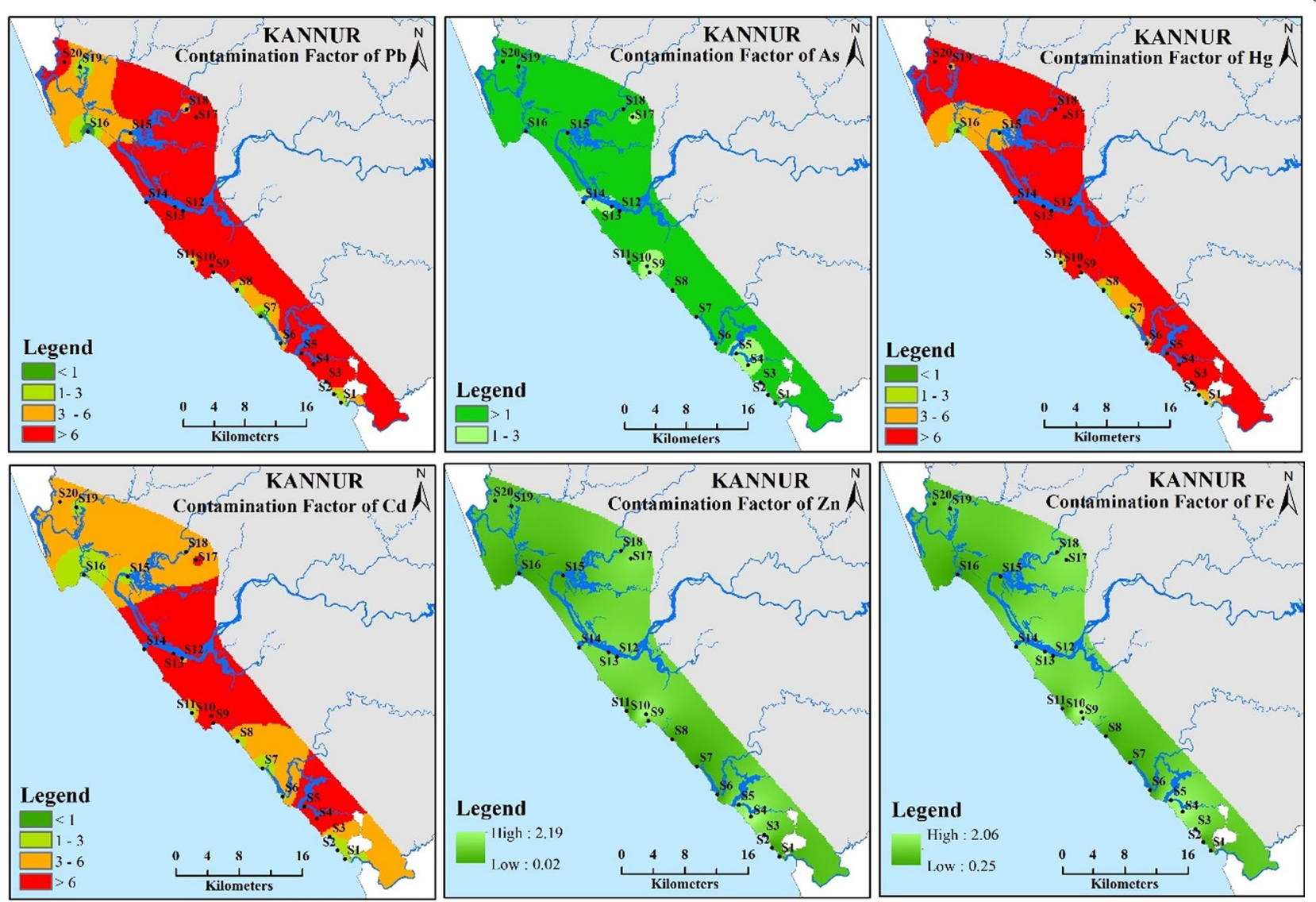

Fig. 5 Spatial distribution of contamination factor of heavy metals

contamination ranges from 3.717 (Chootad Beach) to 97.515 (Kannur New Bus Stand) with a mean value of 31.68. A very high degree of contamination due to heavy metals is observed in the sampling locations such as Thalassery Market, Co-operative Hospital Thalassery, Kannur New Bus Stand, Valapattanam, Azhikkal Port Jetty, Azhikkal, and Thaliparamba, and it indicates that a serious anthropogenic pollution is present in these regions.

\section{Conclusions}

The study shows that the primary source of heavy metal contamination in the study area is mostly by the anthropogenic activities due to the rapid increase of urbanization in Kannur district. The enhanced level of heavy metal concentration in the major towns of Kannur district shows how far the process of urbanization has made an impact of contaminating the environment. The improper solid waste management and untreated wastewater disposal in and around the study area influence the heavy metal contamination. The wastewater treated in treatment plants before discharging to the nearby waterbodies will improve the water quality in that region. With further development in the process of urbanization in the district, greater attention should be paid to decrease the contamination of heavy metals due to the anthropogenic activities. A detailed masterplan for solid waste management and wastewater treatment for each city and periodical evaluation of pollutant origins and development of practical strategies for remediating pollutants discharge is needed to reduce the heavy metal contamination in the study area. 

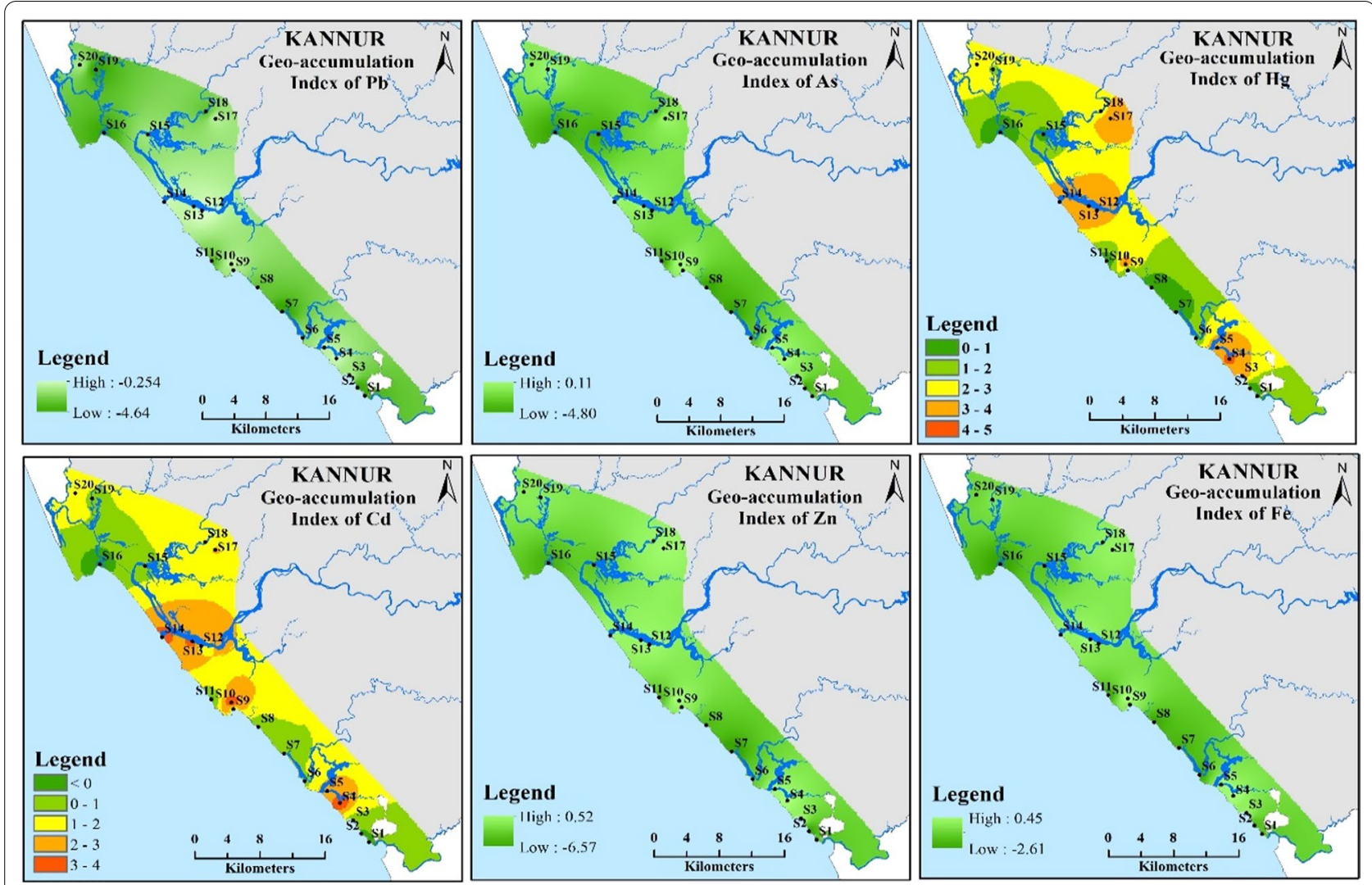

Fig. 6 Spatial distribution of geo-accumulation index of heavy metals
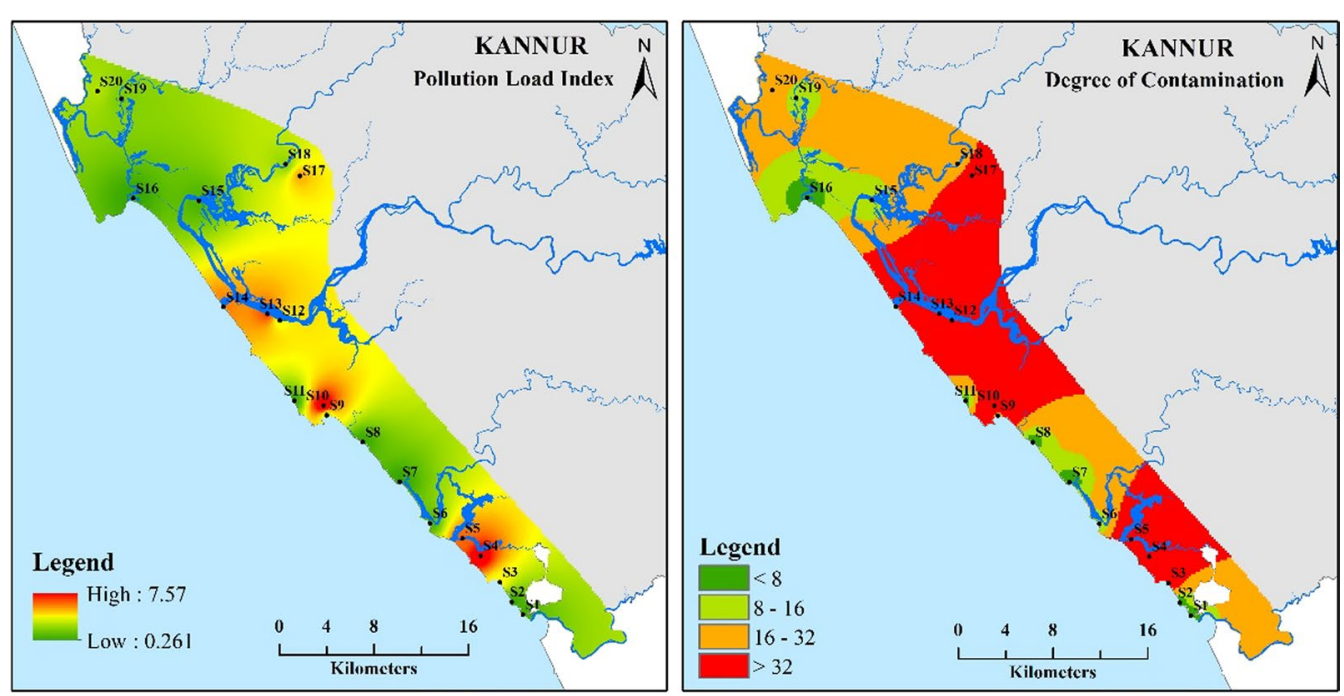

Fig. 7 Spatial distribution of pollution load index and degree of contamination 


\section{Abbreviations}

XRF: X-ray fluorescence spectrometer; GNSS: Global Navigation Satellite System; Arc GIS: Area coded geographic information system; LULC: Land use/ land cover; kg: Kilogram; EF: Enrichment factor; CF: Contamination factor; I geo: Geo-accumulation index; PLI: Pollution load index; $C_{d}$ : Degree of contamination; ppm: Parts per million.

\section{Acknowledgements}

The technical help received from Mr. Mithun Raj P. R. is gratefully acknowledged.

\section{Authors' contributions}

The sample collection and mineral analysis have carried out by the authors KPS and VV. Analysis and interpretation of the data were done by KPS, TKP, and GJ. The cartographic analysis of the study was executed by KPS and TKP. The major contributors in writing manuscript were KPS and V. All authors read and approved the final manuscript.

\section{Funding}

The work was self-funded by the authors.

\section{Availability of data and materials}

All data generated or analysed during the present investigation are included in this published article.

\section{Declarations}

\section{Ethics approval and consent to participate}

Not applicable.

\section{Consent for publication}

Not applicable.

\section{Competing interests}

The authors declare that they have no competing interests.

\section{Author details}

${ }^{1}$ Department of Geography, Kannur University, Payyanur Campus, Edat, Kannur, Kerala 670327, India. ${ }^{2}$ Department of Studies and Research in Physics, Payyanur College, Edat, Kannur, Kerala 670327, India.

Received: 7 October 2021 Accepted: 19 December 2021

Published online: 04 January 2022

\section{References}

Abbas ST, Sarfraz M, Mehdi SM, Hassan G (2007) Trace elements accumulation in soil and rice plants irrigated with the contaminated water. Soil Tillage Res 94:503-509

Alam MGM, Snow ET, Tanaka A (2003) Arsenic and heavy metal contamination of vegetables grown in Samta village, Bangladesh. Sci Total Environ 308:83-96

Alfaifi H, El-Sorogy AS, Qaysi S, Kahal A, Almadani S, Alshehri F, Zaidi FK (2021) Evaluation of heavy metal contamination and groundwater quality along the Red Sea coast, southern Saudi Arabia. Mar Pollut Bull 163:111975

Asa SC, Rath P, Panda UC, Parhi PK, Bramha S (2013) Application of sequential leaching, risk indices and multivariate statistics to evaluate heavy metal contamination of estuarine sediments: Dhamara Estuary, East Coast of India. Environ Monit Assess 185(8):6719-6737

Banerjee ADK (2003) Heavy metal levels and solid phase speciation in street dusts of Delhi, Delhi. Environ Pollut 123:95-105

Bramha SN, Mohanty AK, Satpathy KK, Kanagasabapathy KV, Panigrahi S, Samantara MK, Prasad MVR (2014) Heavy metal content in the beach sediment with respect to contamination levels and sediment quality guidelines: a study at Kalpakkam coast, southeast coast of India. Environ Earth Sci 72(11):4463-4472

Bryan GW, Langston WJ (1992) Bioavailability, accumulation and effects of heavy metals in sediments with special reference to United Kingdom estuaries: a review. Environ Pollut 76(2):89-131
Chai M, Li R, Tam NFY, Zan Q (2019) Effects of mangrove plant species on accumulation of heavy metals in sediment in a heavily polluted mangrove swamp in Pearl River Estuary, China. Environ Geochem Health 41(1):175-189

Chandrasekaran A, Rajalakshmi A, Ravisankar R, Vijayagopal P, Venkatraman $B$ (2015) Measurements of natural gamma radiations and effects of physico-chemical properties in soils of Yelagiri hills, Tamilnadu India with statistical approach. Procedia Earth Planet Sci 11:531-538

Cihlar J (2000) Land cover mapping of large areas from satellites: status and research priorities. Int J Remote Sens 21(6-7):1093-1114

Del Mastro AM, Londonio A, Rebagliati RJ, Pereyra M, Dawidowski L, Gómez D, Smichowski P (2015) Plasma-based techniques applied to the determination of 17 elements in partitioned top soils. Microchem J 123:224-229

ELTurk M, Abdullah R, Zakaria RM, Bakar NKA (2019) Heavy metal contamination in mangrove sediments in Klang estuary, Malaysia: implication of risk assessment. Estuar Coast Shelf Sci 226:106266

Feng Peng F, Song YH, Yuan P, Cui X, Qiu G (2009) The remediation of heavy metals contaminated sediment. Hazard Mater 161:633-640

Feng J, Zhu X, Wu H, Ning C, Lin G (2017) Distribution and ecological risk assessment of heavy metals in surface sediments of a typical restored mangrove-aquaculture wetland in Shenzhen, China. Mar Pollut Bull 124(2):1033-1039

Fletcher DE, Lindell AH, Seaman JC, Stankus PT, Fletcher ND, Barton CD, Biemiller RA, McArthur JV (2019) Sediment and biota trace element distribution in streams disturbed by upland industrial activity. Environ Toxicol Chem 38:115-131

Ganugapenta S, Nadimikeri J, Chinnapolla SRRB, Ballari L, Madiga R, Nirmala K Tella LP (2018) Assessment of heavy metal pollution from the sediment of Tupilipalem Coast, southeast coast of India. Int J Sedim Res 33(3):294-302

Harbison PAT (1986) Mangrove muds - a sink and a source for trace metals. Mar Pollut Bull 17(6):246-250

He B, Yun Z, Shi J, Jiang G (2013) Research progress of heavy metal pollution in China: Sources, analytical methods, status, and toxicity. Chin Sci Bull 58(2):134-140

Hoch M (2001) Organotin compounds in the environment-an overview. Appl Geochem 16(7-8):719-743

Islam MA, Al-Mamun A, Hossain F, Quraishi SB, Naher K, Khan R, Das S, Tamim U, Hossain SM, Nahid F (2017) Contamination and ecological risk assessment of trace elements in sediments of the rivers of Sundarban mangrove forest, Bangladesh. Mar Pollut Bull 124:356-366

Khan AG, Kuek C, Chaudhry TM, Khoo CS, Hayes WJ (2000) Role of plants, mycorrhizae and phytochelators in heavy metal contaminated land remediation. Chemosphere 41(1-2):197-207

Krishna AK, Govil PK (2004) Heavy metal contamination of soil around Pali industrial area, Rajasthan, India. Environ Geol 47:38-44

Krishna AK, Govil PK (2008) Assessment of heavy metal contamination in soils around Manali industrial area, Chennai, Southern India. Environ Geol 54:1465-1472

Krishna AK, Mohan KR, Murthy NN, Periasamy V, Bipinkumar G, Manohar K, Rao SS (2013) Assessment of heavy metal contamination in soils around chromite mining areas, Nuggihalli, Karnataka, India. Environ Earth Sci 70:699-708

Li X, Yeh AG-O (2000) Modelling sustainable urban development by the integration of constrained cellular automata and GIS. Int J Geogr Inf Sci 14(2):131-152

McGrath SP, Zhao FJ, Lombi E (2001) Plant and rhizosphere processes involved in phytoremediation of metal-contaminated soils. Plant Soil 232:207-214

Nagajyoti PC, Lee KD, Sreekanth TVM (2010) Heavy metals, occurrence and toxicity for plants: a review. Environ Chem Lett 8(3):199-216

Nasehi F, Hassani AH, Monavvari M, Karbassi AR, Khorasani N (2013) Evaluating the metallic pollution of riverine water and sediments: a case study of Aras River. Environ Monit Assess 185(1):197-203

Pandey J, Pandey U (2009) Accumulation of heavy metals in dietary vegetables and cultivated soil horizon in organic farming system in relation to atmospheric deposition in a seasonally dry tropical region of India. Environ Monit Assess 148:61-74

Parth V, Murthy NN, Saxena PR (2011) Assessment of heavy metal contamination in soil around hazardous waste disposal sites in Hyderabad city (India): natural and anthropogenic implications. J Environ Res Manag 2(2):027-034 
Petrelli M, Laeger K, Perugini D (2016) High spatial resolution trace element determination of geological samples by laser ablation quadrupole plasma mass spectrometry: Implications for glass analysis in volcanic products. Geosci J 20(6):851-863. https://doi.org/10.1007/ s12303-016-0007-z

Prakash V, Narayana Y, Saxena M, Deb S, Nagar B, Ramakumar K (2011) Study of transfer of trace elements from soil to medicinal plants in the environment of Mangalore. J Radioanal Nucl Chem 290:103-107

Rattan RK, Datta SP, Chhonkar PK, Suribabu K, Singh AK (2005) Long-term impact of irrigation with sewage effluents on heavy metal content in soils, crops and groundwater-a case study. Agric Ecosyst Environ 109:310-322

Ray AK, Tripathy SC, Patra S, Sarma W (2006) Assessment of Godavari estuarine mangrove ecosystem through trace metal studies. Environ Int 32(2):219-223

Ribeiro C, Couto C, Ribeiro AR, Maia AS, Santos M, Tiritan ME, Pinto E, Almeida AA (2018) Distribution and environmental assessment of trace elements contamination of water, sediments and flora from Douro River estuary, Portugal. Sci Total Environ 639:1381-1393

Rigaud S, Radakovitch O, Couture R-M, Deflandre B, Cossa D, Garnier C, Garnier J-M (2013) Mobility and fluxes of trace elements and nutrients at the sediment-water interface of a lagoon under contrasting water column oxygenation conditions. Appl Geochem 31:35-51

Ross SM (1994) Toxic metals in soil-plant systems. Wiley, Chichester

Santos IR, Silva-Filho EV, Schaefer CE, Albuquerque-Filho MR, Campos LS (2005) Heavy metal contamination in coastal sediments and soils near the Brazilian Antarctic Station, King George Island. Mar Pollut Bull 50(2):185-194

Sayooj VV, Vineethkumar V, Ramesh S, Prakash V (2020) Dynamics of heavy metal accumulation in an endosulfan affected area of Kasaragod district, southwest coast of India. Radiat Prot Environ 43:44

Seaward MRD, Richardson DHS (1989) Atmospheric sources of metal pollution and effects on vegetation. In: Heavy metal tolerance in plants: evolutionary aspects, pp 75-92

Sekabira K, Origa HO, Basamba TA, Mutumba G, Kakudidi E (2010) Assessment of heavy metal pollution in the urban stream sediments and its tributaries. Int J Environ Sci Technol 7(3):435-446

Sharma OP, Bangar KS, Jain R, Sharma PK (2004) Heavy metals accumulation in soils irrigated by municipal and industrial effluent. J Environ Sci Eng 46:65-73

Sheela AM, Letha J, Joseph S, Thomas J (2012) Assessment of heavy metal contamination in coastal lake sediments associated with urbanization: Southern Kerala, India. Lakes Reserv Res Manag 17(2):97-112

Sin SN, Chua H, Lo W, Ng LM (2001) Assessment of heavy metal cations in sediments of Shing Mun River, Hong Kong. Environ Int 26(5-6):297-301

Sivakumar S, Chandrasekaran A, Balaji G, Ravisankar R (2016) Assessment of heavy metal enrichment and the degree of contamination in coastal sediment from South East Coast of Tamilnadu, India. J Heavy Met Toxic Dis 1(2): $1-8$

Tam NFY, Wong YS (1996) Retention and distribution of heavy metals in mangrove soils receiving wastewater. Environ Pollut 94(3):283-291

Tam NF, Wong Y-S (1997) Accumulation and distribution of heavy metals in a simulated mangrove system treated with sewage. In: Asia-Pacific conference on science and management of coastal environment, pp 67-75

Tholkappian M, Ravisankar R, Chandrasekaran A, Jebakumar JPP, Kanagasabapathy KV, Prasad MVR, Satapathy KK (2018) Assessing heavy metal toxicity in sediments of Chennai Coast of Tamil Nadu using Energy Dispersive X-Ray Fluorescence Spectroscopy (EDXRF) with statistical approach. Toxicol Rep 5:173-182

Tokman N, Akman S, Ozeroglu C (2004) Determination of lead, copper and manganese by graphite furnace atomic absorption spectrometry after separation/concentration using a water-soluble polymer. Talanta 63(3):699-703

Turkian KK, Wedpohl KH (1961) World geochemical background value in average shale for metals in stream sediments. Geol Soc Am Bull 72:175-191

Veerasingam S, Venkatachalapathy R, Ramkumar T (2012) Heavy metals and ecological risk assessment in marine sediments of Chennai, India. Carpathian J Earth Environ Sci 7(2):111-124

Veeresh H, Tripathy S, Chaudhuri D, Hart BR, Powell MA (2003) Competitive adsorption behavior of selected heavy metals in three soil types of India amended with fly ash and sewage sludge. Environ Geol 44:363-370
Vineethkumar V, Sayooj V, Shimod KP, Prakash V (2020) Estimation of pollution indices and hazard evaluation from trace elements concentration in coastal sediments of Kerala, Southwest Coast of India. Bull Natl Res Centre 44(1):198. https://doi.org/10.1186/s42269-020-00455-0

Wang Q, Hong H, Yang D, Li J, Chen S, Pan C, Lu H, Liu J, Yan C (2020) Health risk assessment of heavy metal and its mitigation by glomalin-related soil protein in sediments along the South China coast. Environ Pollut 263:114565

Zhao G, Lu Q, Ye S, Yuan H, Ding X, Wang J (2016) Assessment of heavy metal contamination in surface sediments of the west Guangdong coastal region, China. Mar Pollut Bull 108:268-274. https://doi.org/10.1016/j. marpolbul.2016.04.057

\section{Publisher's Note}

Springer Nature remains neutral with regard to jurisdictional claims in published maps and institutional affiliations.

\section{Submit your manuscript to a SpringerOpen ${ }^{\circ}$ journal and benefit from:}

- Convenient online submission

- Rigorous peer review

- Open access: articles freely available online

- High visibility within the field

- Retaining the copyright to your article

Submit your next manuscript at $\gg$ springeropen.com 